\title{
ANDROID-BASED-GAME AND BLENDED LEARNING IN CHEMISTRY: EFFECT ON STUDENTS' SELF-EFFICACY AND ACHIEVEMENT
}

\author{
Nur Fitriyana*, Antuni Wiyarsi, Jaslin Ikhsan, K. H. Sugiyarto \\ Universitas Negeri Yogyakarta, Indonesia \\ *e-mail: nur.fitriyana@uny.ac.id
}

\begin{abstract}
The 21st century learning system demands the use of technology in learning instruction. This research focuses on the comparison between the use of android-based-game and blended learning in the Chemistry subject on the hydrocarbon lesson toward students' self-efficacy and achievement. A quasiexperiment with post-test only design was adopted in this research. A number of 143 eleventh graders from two public senior high schools in Purworejo Regency, Indonesia were selected in a cluster random sampling as the research sample. The sample was classified into three groups depending on the media used, i.e. android-based-game only on face-to-face learning (ABG-FTFL), blended learning only (BL), and both android-based-game and blended learning (ABG-BL). Self-Efficacy Scale (SES) was used to obtain the data of students' self-efficacy while the hydrocarbon test was used to obtain students' achievement. One-way Analysis of Variance, Kruskal Wallis test, and descriptive quantity technique were performed in the data analysis, and it is found that the use of these technologies has a significant effect on the students' self-efficacy and achievement. The use of ABG-BL is better in improving students' self-efficacy while BL is better in enhancing students' achievement. Therefore, the use of android-based-game and blended learning can be emphasized as media in chemistry learning to gain better self-efficacy and achievement among students.
\end{abstract}

\section{Keywords: achievement, android-based-game, blended learning, chemistry, self-efficacy}

\section{GAME BERBASIS ANDROID DAN PEMBELAJARAN BLENDED DI KIMIA: PENGARUH TERHADAP EFIKASI DIRI DAN PRESTASI BELAJAR SISWA}

\begin{abstract}
Abstrak: Pembelajaran abad ke-21 menuntut penggunaan teknologi dalam kegiatan belajar mengajar. Penelitian ini berfokus pada perbandingan penggunaan game berbasis android dan pembelajaran blended pada pembelajaran kimia topik hidrokarbon terhadap efikasi diri dan prestasi belajar siswa. Penelitian ini merupakan penelitian kuasi eksperimen dengan desain post-test only. Sejumlah 143 siswa kelas XI dari dua SMA Negeri di Kabupaten Purworejo yang dipilih secara cluster random sampling dijadikan sebagai sampel penelitian. Sampel diklasifikasikan ke dalam tiga kelompok sesuai dengan media pembelajaran yang digunakan, yaitu kelompok yang menerapkan game berbasis android saja dalam pembelajaran tatap muka (ABG-FTFL), kelompok pembelajaran blended saja (BL), dan kelompok game berbasis android dan pembelajaran blended (ABG-BL). Data efikasi diri siswa dikumpulkan melalui angket efikasi diri, sedangkan data prestasi belajar siswa melalui tes hidrokarbon. Data dianalisis menggunakan teknik ANOVA satu jalur, uji Kruskal Wallis, dan deskriptif kuantitatif. Hasil penelitian menunjukkan adanya pengaruh media berbasis teknologi terhadap efikasi diri dan prestasi belajar siswa. Penggunaan ABG-BL lebih baik dalam meningkatkan efikasi diri siswa, adapun BL lebih baik dalam meningkatkan prestasi belajar siswa. Oleh karena itu, kedua media tersebut harus ditekankan sebagai alternatif media dalam pembelajaran kimia untuk meningkatkan efikasi diri dan prestasi belajar siswa.
\end{abstract}

Kata Kunci: prestasi belajar, game berbasis android, pembelajaran blended, kimia, efikasi diri

\section{INTRODUCTION}

The advancement of science and technology have greatly improved the quality of education. The development of technology facilitated learning instruction in science, for example on the chemistry subject. Chemistry subject has a load density of curriculum, thus there were a bunch of chemistry concepts should 
be transferred to the students. However, there was a limited time allocation to study chemistry in face-to-face learning in the school. These facts bring the chemistry learning less effective. Little effectiveness of chemistry learning leads on students' difficulties in understanding the nature of chemistry concepts which affects the declining of student' learning outcomes (Nordby, Knain, \& Jonsdottir, 2017). Therefore, a support from technology as media in the chemistry learning was required to meet these problems such the utilization of technology on online lectures.

Technology leads the learning instruction not always conducted by face-to-face learning but also through the online learning. Since online learning shows many weaknesses such as obstruct the socialization process, thus a new learning instruction proposed. This new learning instruction combines the interaction and participation of online learning and faceto-face learning. The online learning and faceto-face learning have their own weaknesses and advantages, so it will be better if these advantages on both learning instruction were combined that called blended learning (Tayebinik \& Puteh, 2012). The online phase of blended learning represents the technology usage and being considered within the context that this technology plays a main role in curriculum content delivery, access the learning sources, tasks submission, and online discussion through the asynchronous or synchronous learning systems (Seery \& O'connor, 2015; Williams, Bland, \& Christie, 2008).

The synchronous online learning occurs directly when the students and the teacher can interact at the same time. Among all of the available distance teaching technologies, video conference is very similar to formal classroom learning and therefore it belongs to synchronous online learning (Pandey \& Pande, 2014). The video conference is very potential to enrich the online leraning activity, to deliver the curriculum content, and to manage students' assignment that require direct responses among the teacher and the students (Martin, 2005). Hence, the present of video conference offers an alternative way in overcoming the load density of chemistry curriculum. Unfortunately, the video conference is rarely used in the educational field and there is little research had been conducting the use of video conference in the teaching instruction
(Yasar \& Adiguzel, 2010).

On the other hand, the asynchronous online learning engages students in exchanging ideas or information without somebody involvement at the same time. Thus, a learning management system could support the asynchronous online phase of blended learning (Cigdemoglu, Arslan, \& Akay, 2011). The function of learning management system is to provide materials, support collaboration, assess students' performance, record students' data, and produce useful reports in order to increase the effectiveness of learning instruction. Thus, it could increase students' metacognitive awareness and learning autonomy (Gulbinskienè, Masoodi, \& Šliogerienè, 2017). The use of blended learning will facilitate mobile learning; thus the learning process occurs in a flexible way that improves students' learning outcome in chemistry. However, the blended learning in chemistry still rarely implemented, yet it offers to develop students' interest and motivation in learning chemistry such their efficacy.

Self-efficacy is one of motivational beliefs that is based on the expectancy value model (Eggen \& Kauchak, 2010). Bandura (1997) defined self-efficacy as a person's belief about their ability to execute and organize an action to achieve desired goals. Learners self-efficacy could be identified by their task orientation, effort and persistence, beliefs, and performance. In the term of task orientation, students with higher self-efficacy tend to choose and accomplish challenging task (Uzuntiryaki, 2008; Zimmerman, 2000). They use a high effort and persistence in dealing with certain task (Santrock, 2011) and have a high believe to be success in certain activity (Ormrod, 2003). Further, in the performance dimension, they tend to have better work compared with others who have same abilities (Uzuntiryaki, 2008). Therefore, among the various aspects that are correlated with motivation, self-efficacy was critically considered especially in the difficult lesson such as chemistry.

Generally, students' difficulty in learning chemistry caused by the abstractness of chemical concepts (Sirhan, 2007), teacherimposed learning model, and lack of teacher support (Woldeamanuel, Atagana, \& Engida, 2014). One of chemistry lesson that considered to be difficult is hydrocarbon. The hydrocarbon 
captures the concept of uniqueness of carbon atom and the classification of hydrocarbon, structure and chemical nomenclature of hydrocarbon, isomerism and physical properties of hydrocarbon, and hydrocarbon reaction. Many students considering hydrocarbon as a difficult subject due to the combination of the letters and numbers in making hydrocarbon structures, this combination makes the abstractness concept of hydrocarbon (Sarkodie \& Adu-gyamfi, 2015; Wiyarsi, Pratomo, \& Priyambodo, 2020). Though, an appropriate learning media is needed to make hydrocarbon concept easily understandable. Still, the media that facilitate students to learn hydrocarbon is available but it still seldom implemented in the teaching activities.

Phrased differently, an educational game could be used as innovative media in chemistry learning process. This educational game increases students' attention, presents interactive learning process, and provides an innovative learning environment (Newby, Stepich, Lehman, \& Russel, 2006). The students could follow the rules and strive to achieve challenging goals which foster students' self-efficacy. Moreover, the presence of android-based-game was improved the use of mobile learning as students' independent learning source (Calimag, Mugel, Conde, \& Aquino, 2014). This independent learning source makes students more confident in their capabilities. Accordingly, the present of this game could elicit students' efficacy in learning chemistry. As an alternative choice, the android-based-game can be used as innovative learning, matches the desired learning strategy (Jeng, Wu, Huang, Tan, \& Yang, 2010).

The use of android-based-game affects students' behaviour such giving pleasure, positive learning experience, and positive effect toward students' achievement (Jabbour, 2014). The android-based-game facilitates students to learn anytime and anywhere because it consists of the competence that students' master during the learning process, summary of learning materials on HCK, and exercise which packaged in the game form. Since the students could learn the teaching materials in interesting way, thus it helps the increasing of students' achievement. This android-based-game has developed by many researchers, but the exists of the androidbased-game in chemistry is infrequently used.
Considering aforementioned discussion, the android-based-game and blended learning may give different effect on students' selfefficacy and achievement. The use of androidbased-game only or blended learning only may bring significant effect on students' self-efficacy and achievement. Still, the combination between the two media may give more effect on these two aspects. However, the android-based-game provide an opportunity to foster students' selfefficacy only or students' achievement only since students may consider the android-based-game just giving pleasure in their chemistry learning activities (Jabbour, 2014). Further, the successful of blended learning implementation is depends on students' self-regulated learning. Thus, if the students did not well regulate themselves during the experimental manipulation process, it could affect the findings on this research that is students' self-efficacy and achievement. Moreover, the correlation among students' selfefficacy with their achievement still debated since some works revealed the two variables positively related (Shaine, 2015; Ramnarain \& Ramaila, 2018) while the other work found that students' self-efficacy is not a good predictor towards students' achievement (Abulibdeh \& Hasan, 2011). Therefore, the current study intends to explore the effect of ABG-FTFL, BL, and ABG-BL on: (1) students' self-efficacy and (2) students' achievement.

\section{METHODS \\ Research Design}

A quasi-experiment with post-test only design was adopted in this research. Since this design has internal threat on the previous condition of the learners, the researchers analyse the learners condition first before used them as the research sample (see sample of research section). Phrased differently, the independent variable of this research was the implementation of android-based-game and video conference on blended learning. Meanwhile, the dependent variables measured in this research were students' self-efficacy and students' achievement. This research focused on the comparison of the use of technology based media. Thus, there were three classes with different implementation of technology based media used in this research. Since this research adopted post-test only design, the data of students' self-efficacy 
and achievement were collected after the experimental manipulations was given on each class. The research design of the study illustrates in the Table 1.

Table 1. Research Design of the Study

\begin{tabular}{lllll}
\hline \multirow{2}{*}{ Students Group } & Treatment & Post-test & \\
\cline { 2 - 5 } & $\begin{array}{l}\text { Android-based- } \\
\text { game }\end{array}$ & $\begin{array}{l}\text { Blended } \\
\text { Learning }\end{array}$ & $\begin{array}{l}\text { Self-efficacy } \\
\text { Scales }\end{array}$ & $\begin{array}{l}\text { Hydrocarbon } \\
\text { Test }\end{array}$ \\
\hline ABG-FTFL & Yes & No & Yes & Yes \\
BL & No & Yes & Yes & Yes \\
ABG-BL & Yes & Yes & Yes & Yes \\
\hline
\end{tabular}

\section{Sample of Research}

The population in this research covering all eleventh graders who have the same characteristics of students in the four public senior high schools in Purworejo Regency, Central Java, Indonesia. The population characteristics in this research having behaviour to communicate and interact in the online phase (Candarli \& Yuksel, 2012), age around 16-17 years old, enrol in science class, use Indonesian chemistry Curriculum of 2013, and have adequate facilities to support blended learning, and have a very good school accreditation. Thus, two steps of cluster random sampling were used to choose the school and to establish the research samples. In the first cluster random sampling, the researchers randomly pick two schools out of a total of four schools in the population. The first school consist of eight eleventh science grader classes, while the second school covers of five eleventh science grader classes. Therefore, the research sample in this study were drawn from these two schools.

After that, to establish the research sample, the second step of cluster random sampling was held toward both schools. The analysis of students' characteristics and students' prior knowledge in chemistry were analysed as the initial step to establish the research sample. The students' characteristics analysis was conducted by an observation and interview activities toward chemistry teachers on both schools. Further, in order to examine students' prior knowledge in chemistry, analysis of previous students' summative test data was performed. The analysis of students' summative test data was held by one-way ANOVA technique. The cluster random sampling was conducted immediately if there were no difference in the term of students' characteristics and students' prior knowledge in chemistry on each class of the two schools. However, if there were found any differences among the classes, the class which being different are discarded, thus the cluster random sampling held with the remaining classes.

The finding on one-way ANOVA analysis revealed that there was no difference of students' prior knowledge among the classes on each school ( $p$-value of first school $.681>.05$ and second school $.414>.000)$. Further, in the term of students' characteristics, the students on all of the classes from the two schools signified no difference. Hence, three classes from each school were randomly chosen as the research sample. A total of 143 students $(N=143)$ came from 6 classes were participated in this research. This number of research samples were classified into three classes depending the technology based media used in the teaching learning, ABG-FTFL of 50 students; BL of 45 students; and ABG-BL of 48 students.

\section{Instrument of Research}

Two types of data were obtained in this research, the students' self-efficacy and achievement data. The data of students' selfefficacy was measured by self-efficacy scale while the students' achievement was measured by hydrocarbon test for each class. The self-efficacy scale and hydrocarbon test were developed by authors.

\section{Self-Efficacy Scale (SES)}

The initial Self-Efficacy Scale (SES) consists of 30 statements with four points of Likert-type scales (from 1 point $=$ never to 4 point $=$ always). Prior to use, the validity and reliability of SES were carried out. A group of expert from Psychology and Chemistry Education Department were confirmed the content and face 
validity of the SES by giving feedback and mark on each item of SES. Necessary revisions were made following the feedbacks from the expert. While, the mark on each item was analysed following Aiken's V analysis. The findings on Aiken's $\mathrm{V}$ analysis implied that 4 items did not have a good validity. Thus, as many as 26 items of SES were used in the next pilot study as well as empirical validity.

The empirical validity was conducted by a paper-pencil administration towards 342 students. This data was analysed using Item Response Theory (IRT) analysis and it was found that a total of 23 items were suitable with the Rasch model. Thus, the final version of SES consists of 23 items and it use to obtain the data of students' self-efficacy. In addition, the internal consistency of the SES using Cronbach's alpha was found to be .72 . According to Gliem \& Gliem (2003) this value indicates that SES has an acceptable category of reliability. Therefore, SES was a good instrument to collect the data of students' self-efficacy. The distribution of indicators on the SES instrument presented in the Table 2.

Table 2. Distribution Indicators on the SES Instrument

\begin{tabular}{llc}
\hline Aspect & Indicators & $\begin{array}{c}\text { Number } \\
\text { of Items }\end{array}$ \\
\hline Task orientation & Choose and solve challenging and difficult hydrocarbon task & 4 \\
Effort and persistence & Expend high effort when dealing with challenging tasks & 4 \\
& Prepare more time to solve difficult hydrocarbon concept & 3 \\
Beliefs & Control stress and anxiety when goals aren't met & 3 \\
& Believe they will success and in control of their environment & 4 \\
Performance & Compare their performance with others who have same ability & 5 \\
\hline \multicolumn{2}{c}{ Total } & $\mathbf{2 3}$ \\
\hline
\end{tabular}

\section{Hydrocarbon Test}

A hydrocarbon test consists of 26-points of multiple choice questions with five alternative answers and 4-points of essay post-test were used to obtain the data of students' achievement. The hydrocarbon test was constructed based on the four main concepts of hydrocarbon lesson and the indicators of cognitive level of revised Bloom Taxonomy. The validity and reliability of the hydrocarbon test were carried out before the hydrocarbon test was administered. The validity of the hydrocarbon test consisting the content and face validity was conducted toward a group of expert from Chemistry Education Department. Necessary revision according to the comments of the experts were made.
The empirical validity was obtained by a paper-pencil administration within 122 students who have recently completed the hydrocarbon lesson. These data of paper-pencil test were analysed according to IRT. The result of the analysis showed that all of the items on hydrocarbon test were fit with the Rasch model. In addition, the reliability of the hydrocarbon test was found to be highly reliable with Cronbach's alpha value of .95 (Gliem \& Gliem, 2003). Thus, it can be used as a good tool to examine students' achievement. The distribution of Hydrocarbon Content Knowledge (HCK) with the cognitive levels following to Bloom Taxonomy are shown in the Table 3.

Table 3. The Distribution of Content and Cognitive Level of Hydrocarbon Test

\begin{tabular}{lcccc}
\hline \multirow{2}{*}{ HCK } & \multicolumn{3}{c}{ Number of items on the Cognitive Level } \\
\cline { 2 - 5 } & $\mathbf{C 1}$ & $\mathbf{C 2}$ & $\mathbf{C 3}$ & $\mathbf{C 4 , 5 , 6}$ \\
\hline $\begin{array}{l}\text { The uniqueness of carbon atom and classification of } \\
\text { hydrocarbon }\end{array}$ & 1 & 1 & 4 & 3 \\
Structure and chemical nomenclature of hydrocarbon & 1 & 2 & 3 & 2 \\
Isomerism and physical properties of hydrocarbon & - & - & 2 & 7 \\
Hydrocarbon reaction & - & - & - & 4 \\
\hline Total & $\mathbf{2}$ & $\mathbf{3}$ & $\mathbf{9}$ & $\mathbf{1 6}$ \\
\hline
\end{tabular}




\section{Procedures of Research}

The use of android-based-game and video conference in the hydrocarbon lesson toward students' self-efficacy and achievement were conducted. The class that use blended learning consists the combination of face-to-face and online phase learning instruction. While, the class that employs android-based-game only, the learning process was conducted by face-toface teaching learning (the traditionally learning instruction in Indonesia).

The face-to-face phase teaching-learning held in six weeks with 90-minute time allocation. The three student groups used the same learning model that is the $5 \mathrm{E}$ learning cycle. A lesson plan and students' worksheet on each HCK were prepared during teaching intervention. As an example in the first meeting, the learning process was initiated by the Engage process through presenting several figures such as satay, roasted corn, and firewood. The teacher asked the students to observe the characteristics among the three figures and asked several questions related the presented figures. To answer these questions, in the Exploration process, the three student groups were involved in the same experiment. After the students finishing the experiment, they interpret the result of the experiment and correlate with the literature they had learned. The students present the result of the experiment in front of the class as the Explanation step. After that, the students need to finish the worksheet by answering several questions provided then they need to conclude the result of the experiment that held during the Elaboration and Evaluation process.

In the online learning phase of asynchronous learning, a Learning Management System (LMS) was used. The teaching materials were uploaded to the LMS before the face-toface learning was held. Hence, the students will learn and prepare the teaching material before the face-to-face learning was conducted. In addition, the students submit their assignment given by the teacher into LMS. Since, the due time on task submission on LMS was set, it makes the students well managing their selves. While, in the ABG-FTFL group, the students could access the teaching-learning material only when they met the teacher because no online phase teaching-learning was held in this group. Similarly, the teacher already told the students in the ABG-FTFL group that the learning material can be requested directly from the teacher before the learning process was held. Moreover, for the students' assignment, the students submitted directly the assignment to the teacher before the due time.

In the term of synchronous online learning, the video conference was used in the learning activities to deliver the content of hydrocarbon lesson that was not mastered yet by the students. Thus, the teacher delivers and discuss the concept on HCK covering uniqueness of carbon atom and the classification of hydrocarbon, structure and chemical nomenclature of hydrocarbon, isomerism and physical properties of hydrocarbon, and hydrocarbon reaction as supplement of FTFL. The online learning was conducted in student centred learning, therefore it was conducted by discussion activities among the students and the teacher. Certainly, the teacher gave the same additional learning time to discuss the learning materials in each group. The $\mathrm{BL}$ and $\mathrm{ABG}-\mathrm{BL}$ student groups held the discussion forum in the online phase of teaching-learning instruction. However, for the ABG-FTFL group, the discussion forum held in the face-to-face learning when the teacher and the students have free time. The additional time for the discussion was conducted in every week during the research.

The last, in the term of android-basedgame, the students were asked the frequencies in utilizing the android-based-game for every week. The students gave several times to play the android-based-game in the face-to-face learning in the term of reading the summary material and solving the problems provided in the game. The android-based-game makes a flexible and joyful chemistry learning because it contains an interesting summary of material on HCK. The android-based-game provides an exercise on each HCK in the game form. Consequently, the additional learning time frame and the interactive learning source to the students were provided through the android-based-game and the online phase of blended learning. While, in the BL student group that did not apply the android-based-game in hydrocarbon lesson, they were given several times to read the summary of the material they have and conducted a quiz about the hydrocarbon concept. 


\section{Data Analysis}

One-way ANOVA was used to analyse the effect of teaching intervention on students' achievement while Kruskal Wallis test was performed to examine the influence on students' self-efficacy. Moreover, to determine the better technology based media in improving students' self-efficacy and achievement, the descriptive quantity by categorizing the score obtained from SES and hydrocarbon test into five levels categories following Gronlund \& Linn (1990) were used.

\section{RESULTS AND DISCUSSION Results}

According to the data obtained from SES and hydrocarbon test, the descriptive statistics consisting of students' mean score and standard deviation of self-efficacy and achievement were presented in the Table 4 . The Table 4 shows that ABG-BL has a better students' selfefficacy mean score compared with the other two classes. A good mean score category of students' self-efficacy obtained from the BL and
ABG-BL groups, while the ABG-FTFL only gained sufficient category. Different results were obtained from the students' achievement mean score. The three classes used in this research have a good category mean score. However, BL group had the highest students' achievement mean score.

Study Question One: How was the effect of $A B G$-FTFL, $B L$, and $A B G-B L$ on students'selfefficacy?

To determine the effect of teaching intervention on students' self-efficacy, Kruskal Wallis test was conducted, Table 5 presents the values. The findings on Table 5 show there were found significantly different on the aspect of task orientation and performance of self-efficacy but no significantly different on the effort and persistence also belief aspect among the three students' group. The differences found on the task orientation and performance dimension of self-efficacy in favour of ABG-BL group. Therefore, the findings of this research implied that ABG-BL group had an effects on students' self-efficacy.

Table 4. Descriptive Statistics on Students' Self-efficacy and Achievement

\begin{tabular}{llccccccc}
\hline $\begin{array}{l}\text { Dependent } \\
\text { Variable }\end{array}$ & $\begin{array}{l}\text { Student } \\
\text { Group }\end{array}$ & $\boldsymbol{N}$ & Min & Max & $\begin{array}{c}\text { Ideal } \\
\text { Score }\end{array}$ & Mean & Category & SD \\
\hline Self-efficacy & ABG-FTFL & 50 & 35 & 81 & 92 & 60.89 & Sufficient & 9.479 \\
& BL & 45 & 51 & 78 & 92 & 64.44 & Good & 7.942 \\
& ABG-BL & 48 & 49 & 89 & 92 & 67.93 & Good & 9.705 \\
Achievement & ABG-FTFL & 50 & 42 & 96 & 100 & 73.24 & Good & 14.646 \\
& BL & 45 & 34 & 94 & 100 & 76.60 & Good & 11.898 \\
& ABG-BL & 48 & 46 & 94 & 100 & 71.19 & Good & 13.842 \\
\hline
\end{tabular}

Table 5. The Results of Kruskal Wallis Test on Students' Self-efficacy

\begin{tabular}{|c|c|c|c|c|c|c|c|}
\hline Student Group & Mean & $S D$ & & $\begin{array}{l}\text { Mean } \\
\text { Rank }\end{array}$ & $d f$ & Chi Square & $\left.p^{*}\right)$ \\
\hline Task orientation & 11.103 & 2.581 & $\begin{array}{l}\text { ABG-FTFL } \\
\text { BL } \\
\text { ABG-BL }\end{array}$ & $\begin{array}{l}60.88 \\
58.62 \\
96.13\end{array}$ & 2 & 24.597 & .000 \\
\hline Effort and persistence & 19.355 & 3.544 & $\begin{array}{l}\text { ABG-FTFL } \\
\text { BL } \\
\text { ABG-BL }\end{array}$ & $\begin{array}{l}63.63 \\
79.08 \\
74.08\end{array}$ & 2 & 3.477 & .176 \\
\hline Belief & 19.452 & 3.379 & $\begin{array}{l}\text { ABG-FTFL } \\
\text { BL } \\
\text { ABG-BL }\end{array}$ & $\begin{array}{l}63.35 \\
70.78 \\
82.16\end{array}$ & 2 & 5.105 & .078 \\
\hline Performance & 14.456 & 2.599 & $\begin{array}{l}\text { ABG-FTFL } \\
\text { BL } \\
\text { ABG-BL }\end{array}$ & $\begin{array}{l}52.67 \\
74.98 \\
89.34\end{array}$ & 2 & 19.545 & .000 \\
\hline
\end{tabular}

*)statistical significance level of .05 
In addition, the data of students' selfefficacy were classified into excellent, good, fair, poor, and very poor category according to the descriptive quantity technique. This analysis aims to determine the better media used in enhancing students' self-efficacy. The analysis was conducted on each aspect of students' self-efficacy among the three students' groups. Moreover, the profile of students' self-efficacy in each group also revealed. Thus, the level of students' self-efficacy among the three students group were presented. The findings on this analysis are shown in the Table 6 .

Table 6 describes that the distribution level of students' self-efficacy aspects in ABG$\mathrm{BL}$ were found dominant on good category. The students in ABG-BL have a good category of self-efficacy in the task orientation, belief, and performance aspects. However, the effort and persistence aspect only signified fair category. The score of the effort and persistence aspect in $\mathrm{BL}$ was higher than $\mathrm{ABG}-\mathrm{BL}$, but according to the result of Kruskal Wallis test on Table 5, there was no significantly difference. Moreover, the profile of students' self-efficacy in ABG-BL describes a better performance compared to the other two classes. The percentage of students' self-efficacy in ABG-BL dominant on good category and there were $17 \%$ of students who had very good category. Hence, ABG-BL is the better media in improving students' self-efficacy in this research compared than the use of ABGFTFL only or BL only.

Table 6. The Findings of Descriptive Quantity on Students' Self-Efficacy

\begin{tabular}{|c|c|c|c|c|c|c|}
\hline & \multirow[b]{2}{*}{$\begin{array}{l}\text { Student } \\
\text { Group }\end{array}$} & \multicolumn{5}{|c|}{ Aspect of Self-efficacy } \\
\hline & & $\begin{array}{l}\text { Self- } \\
\text { efficacy } \\
(N=\mathbf{2 3})\end{array}$ & $\begin{array}{l}\text { Task } \\
\text { orientation } \\
(N=4)\end{array}$ & $\begin{array}{l}\text { Effort \& } \\
\text { Persistence } \\
(N=7)\end{array}$ & $\begin{array}{l}\text { Belief } \\
(N=7)\end{array}$ & $\begin{array}{l}\text { Performance } \\
(N=5)\end{array}$ \\
\hline \multicolumn{2}{|l|}{ Ideal score } & 92 & 16 & 28 & 28 & 20 \\
\hline \multirow[t]{3}{*}{ Mean } & ABG-FTFL & 60.89 & 10.41 & 18.70 & 18.53 & 13.25 \\
\hline & $\mathrm{BL}$ & 64.44 & 10.30 & 19.85 & 19.59 & 14.70 \\
\hline & ABG-BL & 67.93 & 12.58 & 19.58 & 20.28 & 15.49 \\
\hline \multirow[t]{3}{*}{ Level } & ABG-FTFL & Fair & Fair & Fair & Fair & Fair \\
\hline & $\mathrm{BL}$ & Good & Fair & Good & Fair & Good \\
\hline & ABG-BL & Good & Good & Fair & Good & Good \\
\hline \multicolumn{7}{|c|}{ Percentage of Students' Self-efficacy in Each Level Category } \\
\hline \multirow{2}{*}{ Interval } & \multirow{2}{*}{ Category } & \multicolumn{5}{|c|}{ Percentage $(\%)$} \\
\hline & & \multicolumn{2}{|c|}{ ABG-FTFL } & BL & & ABG-BL \\
\hline $78.2-92$ & Very good & \multicolumn{2}{|c|}{4} & 0 & & 17 \\
\hline $64.4-78.1$ & Good & \multicolumn{2}{|c|}{32} & 53 & & 46 \\
\hline $50.6-64.3$ & Fair & \multicolumn{2}{|c|}{50} & 47 & & 35 \\
\hline $36.8-50.5$ & Poor & \multicolumn{2}{|c|}{12} & 0 & & 2 \\
\hline $0-36.7$ & Very poor & \multicolumn{2}{|c|}{2} & 0 & & 0 \\
\hline
\end{tabular}

Study Question Two: How was the effect of $A B G-F T F L, B L$, and $A B G-B L$ on students' achievement?

The results of one-way ANOVA determining the significantly different on students' achievement among the three students' group are depicted in the Table 7. As presented in Table 7, the results of one-way ANOVA technique revealed that there were significantly different of the three HCK consisting of the uniqueness and hydrocarbon classification, structure and nomenclature of hydrocarbon, and hydrocarbon reaction that explained $7.2 \%$; $4.9 \%$; and $5.0 \%$ of the variance in students' achievement respectively. However, on the isomerism and physical properties of HCK, there was no significantly different. 
Table 7. The Results of One-way ANOVA on Students' Achievement

\begin{tabular}{|c|c|c|c|c|c|c|c|}
\hline $\begin{array}{l}\text { Hydrocarbon } \\
\text { Content } \\
\text { Knowledge } \\
\end{array}$ & & $\begin{array}{l}\text { Sum of } \\
\text { Squares }\end{array}$ & $d f$ & $\begin{array}{l}\text { Mean } \\
\text { Square }\end{array}$ & $F$ & $P^{*}$ & $\begin{array}{l}\text { Partial } \\
\text { Eta } \\
\text { Squared }\end{array}$ \\
\hline \multirow{3}{*}{$\begin{array}{l}\text { The uniqueness } \\
\text { and classification }\end{array}$} & Between groups & 254.188 & 2 & 127.094 & 5.431 & .005 & .072 \\
\hline & Within groups & 3276.441 & 140 & 23.403 & & & \\
\hline & Total & 3530.629 & 142 & & & & \\
\hline \multirow{3}{*}{$\begin{array}{l}\text { Structure and } \\
\text { nomenclature }\end{array}$} & Between groups & 76.830 & 2 & 38.415 & 3.588 & .030 & .049 \\
\hline & Within groups & 1499.058 & 140 & 10.708 & & & \\
\hline & Total & 1575.888 & 142 & & & & \\
\hline \multirow[t]{3}{*}{ Reaction } & Between groups & 201.175 & 2 & 100.588 & 3.649 & .029 & .050 \\
\hline & Within groups & 3858.797 & 140 & 27.563 & & & \\
\hline & Total & 4059.972 & 142 & & & & \\
\hline \multirow{3}{*}{$\begin{array}{l}\text { Isomerism } \\
\text { and physical } \\
\text { properties }\end{array}$} & Between groups & 165.335 & 2 & 82.668 & 3.034 & .051 & .042 \\
\hline & Within groups & 3814.399 & 140 & 27.246 & & & \\
\hline & Total & 3979.734 & 142 & & & & \\
\hline
\end{tabular}

Phrased differently, to determine the better media in improving students' achievement, the data of students' achievement on each HCK were analysed following descriptive quantity technique. This analysis was conducted with the three student groups. Moreover, the profile of students' achievement in applying the technology based media on each student group was examined. The results of these two analyses are presented in the Table 8.
According to Table 8, almost all of the three student groups gave the same result that fall into a good category. Meanwhile, based on the profile of students' achievement, it can be concluded that $\mathrm{BL}$ gives better effects on students' achievement since the pupil gained the highest percentage in the good and excellent category compared with the two classes. Thus, BL is the better media in enhancing students' achievement than the ABG-FTFL only or the combination between the two on ABG-BL.

Table 8. Students' Achievement Level of the Research

\begin{tabular}{|c|c|c|c|c|c|c|}
\hline \multirow[b]{2}{*}{ Aspect } & \multirow[b]{2}{*}{ Class } & \multicolumn{5}{|c|}{ Hydrocarbon Content Knowledge } \\
\hline & & $\begin{array}{l}\text { Students' } \\
\text { Achievement } \\
(N=30)\end{array}$ & $\begin{array}{l}\text { Uniqueness \& } \\
\text { Classification } \\
(N=9)\end{array}$ & $\begin{array}{l}\text { Structure \& } \\
\text { Nomenclature } \\
(N=8)\end{array}$ & $\begin{array}{l}\text { Reaction } \\
(N=4)\end{array}$ & $\begin{array}{l}\text { Isomerism } \\
\text { \& Physical } \\
\text { Properties } \\
(N=9)\end{array}$ \\
\hline \multicolumn{2}{|l|}{ Ideal score } & 100 & 28 & 26 & 18 & 28 \\
\hline \multirow[t]{3}{*}{ Mean } & ABG-FTFL & 73.24 & 18.32 & 22.48 & 12.68 & 19.76 \\
\hline & $\mathrm{BL}$ & 76.60 & 19.91 & 22.62 & 13.33 & 20.73 \\
\hline & ABG-BL & 71.19 & 21.54 & 21.00 & 10.54 & 18.10 \\
\hline \multirow[t]{3}{*}{ Level } & ABG-FTFL & Good & Good & Excellent & Good & Good \\
\hline & & Good & Good & Excellent & Good & Good \\
\hline & ABG-BL & Good & Good & Excellent & Fair & Good \\
\hline \multicolumn{7}{|c|}{ Percentage of Students' Achievement in each Level Category } \\
\hline \multirow{2}{*}{ Interval } & \multirow{2}{*}{ Category } & \multicolumn{5}{|c|}{ Percentage (\%) } \\
\hline & & \multicolumn{2}{|c|}{ ABG-FTFL } & BL & \multicolumn{2}{|c|}{ ABG-BL } \\
\hline $81-100$ & Very good & \multicolumn{2}{|c|}{40} & 42 & \multicolumn{2}{|c|}{31} \\
\hline $61-80$ & Good & \multicolumn{2}{|l|}{42} & 49 & \multicolumn{2}{|c|}{40} \\
\hline $41-60$ & Sufficient & \multicolumn{2}{|l|}{18} & 7 & \multicolumn{2}{|c|}{29} \\
\hline $21-40$ & Poor & \multicolumn{2}{|l|}{0} & 2 & \multicolumn{2}{|r|}{0} \\
\hline $0-20$ & Very poor & \multicolumn{2}{|l|}{0} & 0 & \multicolumn{2}{|r|}{0} \\
\hline
\end{tabular}




\section{Discussion}

This section describes the discussion concerning the findings of this research. As the recent development of science and technology, the quality of teaching instruction depend on the skills of the teachers and the students in mastering technology. This skill could be helpful following the needs in creating teaching environments that will change the educational processes (Kuzminska, Morze, \& Smyrnova-Trybulska, 2017). Thus, the effects of varied teaching instruction especially with the embedded of technology should be examine toward varied students' learning outcomes such as self-efficacy and achievement. The result of this research indicates that the use of technology based media on hydrocarbon lesson gives different effect on students' self-efficacy and achievement.

\section{The Effect of $A B G-F T F L, B L$, and $A B G-B L$ on Students'Self-Efficacy}

The findings of this study implied that ABG-BL group had the highest score of students' self-efficacy. Thus, the android-basedgame and blended learning give positive effect on students' self-efficacy. Since the students can freely to access the teaching materials in a flexible way, thus, it will help them to be well prepare to learn the materials in the face-to-face learning instruction. The students are also freely to repeat the hydrocarbon teaching materials that has not been mastered in order to enrich their knowledge. Therefore, the students feel more confident in their abilities that bring the increasing of students' self-efficacy.

The result of this study confirm the previous study by Alqurashi (2016) that revealed students' self-efficacy in LMS user gives positive influence toward students' performance in the blended learning. The students feel satisfied with the availability of learning sources in online phase of blended learning because it is valuable to increase their understanding (Francis \& Shannon, 2013). Similarly, Ozsoy-Gunes, Gunes, \& Kirbaslar (2014) proposed that positive effects on students' self-efficacy was observed as a result of the implementation of technology as a learning assisstant. In line, the result of Nais, Sugiyarto, \& Ikhsan (2018) revealed that hybrid learning that is commonly known as blended learning gives a significant effects on students' self-efficacy. Students that enrolled and used to the blended lerning environments will increase their control in learning (Horzum, 2014). Hence, it is understood that the higher score of students' self-efficacy were caused by their experiences in implementing blended learning and studying the learning materials through the online phase of learning instruction.

The synchronous online instruction of blended learning in this research use video conference as the media. The video conference was utilized as the media in delivering hydrocarbon content since the limited time allocation in the formal education, the online forum discussion if the students find difficulties about the learning materials, and the media to present the task given by the teacher. Hence, the video conference gives an additional time to learn, additional interactive learning sources, and increase the interaction among students and teacher as suggested by Means, Toyama, Murphy, \& Baki (2013). Moreover, Makarem (2015) work showed that the use of online video lectures enriched the traditional face-to-face courses. Therefore, through this activity, the students are more confident in their ability after perceiving blended learning, thus the students' self-efficacy got improved.

In addition, there was a significant difference on the task orientation aspect of selfefficacy in favour of ABG-BL group. Based on the observation, students who use blended learning feel the task given by the teacher through the phase of blended learning is very challenging. They need to master the media used in the online learning phase before they can fulfil the tasks. The result of this research in line with Chen (2014) that revealed the role of technology as online learning media used in the teachinglearning instruction could rank their selfefficacy quite moderate. Another study shows that personal experiences are the most important factor in predicting students' self-efficacy (Yurt, 2014) because those students perceived and constructed their own knowledge (Retnowati \& Aqiilah, 2017). Moreover, most of students were actively participated in the online phase of blended learning which lead a significant different on students' self-efficacy on the three student groups (Nais et al., 2018).

On the other hand, students spend a lot of effort when given the task of modelling of hydrocarbon isomerism. All of the three 
student groups showed the same effort in finishing the challenging task due to the same tasks characteristics with different media used to submit the assignment given by the teacher. Thus, it brings no significant difference was found on the effort and persistence aspect of self-efficacy. Phrased differently, in the case of believe aspect, it found no significant difference among the three classes of the ABG-BL with the highest score followed by the BL, then ABGFTFL groups. The findings of this study was contrast with the previous study that sense of selfefficacy was able to solve the obstacles faced by students in the daily life (Jenaabadi, Nastiezaie, \& Safarzaie, 2017). Thus, the students should be highly believing with their capability in dealing the obstacles.

Furthermore, examining the results on the performance dimension, students' performance on ABG-BL signified the highest score, thus it describes that ABG-BL brings a significant contribution on their efficacy. The finding of this study support the previous work that the presence of blended learning increases academic success and motivation in a meaningful way (Akgündüz \& Akınoğlu, 2017), thus the higher students' motivation leads the increasing students' self-efficacy. This result was in line with the finding on the task orientation aspect that states perceived usefulness is said to be the degree in which an individual believes that online based learning environment would enhance students' performance (Chen, 2014). Hence, significant difference occurred with the highest score of self-efficacy found in ABG-BL followed by BL and ABG-FTFL respectively. Accordingly, the ABG-BL is the best media in increasing students' self-efficacy.

\section{The Effect of $A B G-F T F L, B L$, and $A B G-B L$ on Students'Achievement}

Different result obtained according to the effect on students' achievement. The result of this study showed that the mean score of students' achievement in BL was the highest compared to the other two classes. However, there was no significantly different on the hydrocarbon isomerism content knowledge. The hydrocarbon isomerism has a difficult characteristic, thus the student required to practise in finding the isomerism of hydrocarbon in the face-toface learning. The role of the technology in this research not yet facilitated the student to illustrate the isomerism of hydrocarbon. Hence, to practice the students' skill in understanding the hydrocarbon isomerism, the teacher gives the task to make a model of the hydrocarbon isomerism. However, this task is not giving a significant effect on students' understanding about hydrocarbon isomerism.

Blending educational moda in the form of online and face-to-face classes affect the higher students' satisfication and increasing the teaching efficiency (Bernard, Bros, \& MigdatMikuli, 2017). Yet in this study, considering the advantages of the blended learning such as giving additional learning time and providing a flexible learning way (Dwijonagoro \& Suparno, 2019) which make the students' achievement on the $\mathrm{BL}$ was the highest compared to the other two student groups. The result of this study supported by Abulibdeh \& Hasan (2011) that prove the online phase of blended learning offers an innovative method to promote students' selfefficacy and could affect students' achievement through the interaction of online phase of blended learning. Other researchers i.e. Saritepeci \& Çakır (2015) also confirmed that the use of blended learning had a positive contribution in students' achievement. The face-to-face component was highly contributing in providing the chance for students to ask questions and answers in real time, while the online component found to be very helpful in the term of flexibility and limitless chances to students' practice or revisit the concepts had been discussed in the face-to-face component (Tekane, Pilcher, \& Potgieter, 2019). The results of this study found contrary with the study conducted by Yüksel \& Üniversitesi (2014) that the levels of selfefficacy did not significantly differ with respect to their academic achievement. It was seen that the use of blended learning was highly contribute in improving students' attitude instead of their achievement.

On the other hand, the androidbased-game facilitated the students' to learn hydrocarbon material in a flexible way i.e. before the student falls a-sleep, when waiting for bus school, during the spare time, etc. The androidbased-game was improving the use of mobile learning as the students' independent learning sources (Calimag et al., 2014). The presence of this independent learning sources make the 
students to be more confident in their capability. Although Chuang \& Chen (2005) suggested that the educational games could enhance students' interest on chemistry learning activities that brings students' achievement increase, but this study gives a contrast result. The students that are facilitated with an android-based-game only in the learning instruction have a low scores of students' achievement.

Considering the result on the effects of android-based-game toward students' self-efficacy that gives the lowest effect, it is reasonable if the effect on students' achievement was not really good. Different result was obtained if seeking the students' self-efficacy score on the ABG-BL which gained a highest score compared to the other two classes. Associated with students' self-efficacy score, students' achivement of ABG-BL was the lowest. This fact means that students' self-efficacy score is not a good predictor toward students' achievement. This is in line with Puzziferro (2008) who state that students' self-efficacy in the term of technology implementation was a weak predictor on students' achievement. Therefore, the implementation of BL only brings significant contribution in eliciting students' achievement compared with ABG-FTFL only or combination the two media on ABG-BL.

Finally, research about students' selfefficacy and achievement need to be deeply explores. Technology made the teachers possible to develop a new pedagogical approach by constructing their own learning practices (Kopciewicz \& Bougsiaa, 2018). The use of the combination between android-basedgame and blended learning in this research could be used as a reference to the teacher in promoting students' self-efficacy. Still, the use of blended-learning only is better in promoting students' achievement. There is no doubt that the implementation of another technology based media as interactive learning media might giving significant effects on these two variables. Thus, it needs to be widely developed in order to seek its effectiveness on students' self-efficacy and achievement.

\section{CONCLUSION}

There is a significant effect of androidbased-game and blended learning toward students' self-efficacy and achievement. The students' who used the combination of both technologies based media (android-basedgame and blended learning) gained a better self-efficacy compared to the other two student groups. However, the students who used blended learning only explore a higher students' achievement compared to the both student groups. Hence, the use of android-based-game and blended learning can be emphasized for further studies to gain a better students' selfefficacy, while the use of blended learning only to gain a better students' achievement.

Considering the results of this study, it is recommended to implement android-basedgame and blended learning with varied research samples i.e. toward the students who learn in the school located in the urban and rural area in order to seek the effects on students' self-efficacy and achievement. It is also recommended to vary the proportion of the online and face-to-face phases teaching-learning instruction, thus the most effective proportion comparison between the online and face-to-face learning phase in blended learning will obtained.

\section{ACKNOWLEDGEMENT}

The authors gratefully acknowledge the support of the Indonesian Directorate General of Higher Education for funding this work through "Tim Pascasarjana" grant of 2017.

\section{REFERENCES}

Abulibdeh, E. S., \& Hasan, S. S. S. (2011). E-learning interactions, information technology self efficacy and student achievement at the University of Sharjah, UAE. Australasian Journal of Educational Technology, 27(6), 1014-1025. https://doi. org/10.14742/ajet.926.

Akgündüz, D., \& Akınoğlu, O. (2017). The impact of blended learning and social media-supported learning on the academic success and motivation of the students in science education. Education and Science, 42(191), 69-90. https://doi.org/10.15390/ EB.2017.6444.

Alqurashi, E. (2016). Self-efficacy in online learning environments: A literature review. Contemporary Issues in Education Research, 9(1), 45-52. https:// doi.org/10.19030/cier.v9i1.9549. 
Bandura, A. (1997). Self-efficacy the exercise of control. New York, NY: W. H. Freeman and Company.

Bernard, P., Bros, P., \& Migdat-Mikuli, A. (2017). Influence of blended learning on outcomes of students attending a general chemistry course: Summary of a fiveyear-long study. Chemistry Education Research and Practice, 18, 682-690. https://doi.org/10.1039/c7rp00040e.

Calimag, J. N., Mugel, P. A., Conde, R. S., \& Aquino, L. B. (2014). Ubquitous learning environment using android mobile application. International Journal of Research in Engineering \& Technology, 2(2), 119-128. http://www.impactjournals. us.

Candarli, D., \& Yuksel, H. (2012). Students' perceptions of video-conferencing in the classrooms in higher education. Procedia - Social and Behavioral Sciences, 47, 357-361. https://doi.org/10.1016/j. sbspro.2012.06.663.

Cigdemoglu, C., Arslan, H., \& Akay, H. (2011). A phenomenological study of instructors' experiences on an open source learning management system. Procedia Social and Behavioral Sciences, 28, 790-795. https:// doi.org/10.1016/j.sbspro.2011.11.144.

Chen, Y-L. (2014). A study on student selfefficacy and technology acceptance model within an online task-based learning environment. Journal of Computers, 9(1), 34-43. https://doi.org/10.4304/jcp.9.1.3443.

Chuang, T.-Y., \& Chen, W.-F. (2005). Effect of digital games on children's cognitive achievement. Journal of Multimedia, 2(5), 27-30. https://doi.org/10.4304/ jmm.2.5.27-30.

Dwijonagoro, S., \& Suparno. (2019). Pranatacara learning: Modeling, mind mapping, e-learning, or hybrid learning? Cakrawala Pendidikan, 38(1), 156-173. https://doi.org/10.21831/cp.v38i1.23034.

Eggen, P., \& Kauchak, D. (2010). Educational psychology. New Jersey, NJ: Pearson Merril Prentice Hall.

Francis, R., \& Shannon, S. J. (2013). Engaging with blended learning to improve students' learning outcomes. European Journal of Engineering Education, 38(4), 359-369. https://doi.org/10.1080/03043797.2013.7 66679 .

Gliem, J. A., \& Gliem, R. R. (2003). Calculating, interpreting, and reporting Cronbach's' alpha reliability coefficient for Likert type scales. Midwest Research to Practice Conference in Adult, Continuing, and Community Education, 82-88. http://hdl. handle.net/1805/344.

Gronlund, N. E., \& Linn, R. L. (1990). Measurement and evaluation in teaching. New York, NY: Macmillan Publishing Company.

Gulbinskienė, D., Masoodi, M., \& Šliogerienė, J. (2017). Moodle as virtual learning environment in developing language skills, fostering metacognitive awareness and promoting learner autonomy. Pedagogy, 127(3), 176-185. https://doi. org/10.15823/p.2017.47.

Horzum, M. B. (2014). A longitudinal and cross-sectional research on the learning approaches and transactional distance in students of blended learning. Education and Science, 39(74), 53-56. https://doi. org/10.15390/eb.2014.1858.

Jabbour, K. K. (2014). An analysis of the effect of mobile learning on Lebanese higher education. Informatics in Education, 13(1), 1-15. https://doi.org/10.15388/ infedu.2014.01.

Jenaabadi, H., Nastiezaie, N., \& Safarzaie, H. (2017). The relationship of academic burnout and academic stress with academic self-efficacy among graduate students. The New Educational Review, 49(3), 65-76. https://doi.org/10.15804/ tner.2017.49.3.05.

Jeng, Y. L., Wu, T. T., Huang, Y. M., Tan, Q., \& Yang, S. (2010). The add-on impact 
of mobile applications in learning strategies: A review study. Educational Technology \& Society, 13(3), 3-11. http://www.etc.edu.cn/public/pages/ reference-foreign/59The $\% 20 \mathrm{Add}$ on $\% 20$ Impact $\% 20$ of $\% 20$ Mobile $\% 20$ Applications\%20in\%20Learning\%20 Strategies--A\%20Review\%20Study.pdf.

Kopciewicz, L., \& Bougsiaa, H. (2018). Is technology a magic wand? When tablets' affordances meet teaching practices: Insights on didactic design. The New Educational Review, 51(1), 76-90. https:// doi.org/10.15804/tner.2018.51.1.06.

Kuzminska, O., Morze, N., \& SmyrnovaTrybulska, E. (2017). Flipped learning model: Tools and experience of its implementation in higher education. The New Educational Review, 49(3), 189-200. https://doi.org/10.15804/ tner.2017.49.3.15.

Makarem, S. C. (2015). Using online video lectures to enrich traditional face-toface courses. International Journal of Instruction, 8(2), 155-164. https://doi. org/10.12973/iji.2015.8212a.

Martin, M. (2005). Seeing is believing: The role of video conferencing in distance learning. British Journal of Educational Technology, 36(3), 397-405. https://doi. org/10.1111/j.1467-8535.2005.00471.x.

Means, B., Toyama, Y., Murphy, R., \& Baki, M. (2013). The effectiveness of online and blended learning: A meta-analysis of the empirical literature. Teachers College Record, 115(3), 1-47.

Nais, M. K., Sugiyarto, K. H., \& Ikhsan, J. (2018). The profile of students' selfefficacy using virtual chem-lab in hybrid learning. Journal of Physics: Conference Series, 1097, 012060. https://doi. org/10.1088/1742-6596/1097/1/012060.

Newby, T. J., Stepich, D. A., Lehman, J. D., \& Russel J. D. (2006). Educational technology for teaching and learning. Upper Saddle River, NJ: Pearson Merrill Prentice Hall.
Nordby, M., Knain, E., \& Jonsdottir, G. (2017). Vocational students' meaning-making in school science - negotiating authenticity through multimodal mobile learning. Nordina, 13(1), 52-65. https://doi. org/10.5617/nordina.2976.

Ormrod, J. E. (2003). Educational psychology developing learners. New Jersey, NJ: Pearson Merrill Prentice Hall.

Ozsoy-Gunes, Z., Gunes, I., \& Kirbaslar, M. (2014). Investigation of the relationships between educational internet use selfefficacy and self-regulated learning skills. Procedia-Social and Behavioral Science, 152, 708-713. https://doi.org/10.1016/j. sbspro.2014.09.308.

Pandey, H., \& Pande, P. (2014). Video conferencing: An efficient e-learning tool for distance education. International Journal of Innovation and Scientific Research, 10(2), 308-311. http:// www.ijisr.issr-journals.org/abstract. php?article=IJISR-14-185-01.

Puzziferro, M. (2008). Online technologies self-efficacy and self-regulated learning as predictors of final grade and satisfaction in college-level online courses. American Journal of Distance Education, 22(2), 72-89. https://doi. org/10.1080/08923640802039024.

Ramnarain, U., \& Ramaila, S. (2018). The relationship between chemistry selfefficacy of South African first year university students and their academic performance. Chemistry Education Research and Practice, 19(1), 60-67. https://doi.org/10.1039/c7rp00110j.

Retnowati, E., \& Aqiila.(2017). The effectiveness of dyad strategy during mathematics learning based on CORE model. Cakrawala Pendidikan, 36(1), 13-23. https://doi.org/10.21831/cp.v35i1.12628.

Santrock, J. W. (2011). Educational psychology. New York, NY: The MC Graw-Hill Companies, Inc.

Sarıtepeci, M., \& Çakır, H. (2015). The effect 
of blended learning environments on student's academic achievement and student engagement: A study on social studies course. Education and Science, 40(177), 203-216. https://doi. org/10.15390/EB.2015.2592.

Sarkodie, P. S., \& Adu-gyamfi, K. (2015). Improving students' performance in naming and writing structural formulae of hydrocarbons using the ball-andstick models. Bulgarian Journal of Science Education, 24(2), 203219. http://khimiya.org/show issue. php? $=2015 \&$ vol $=24 \&$ issue $=2 \& \mathrm{i} \_\overline{\mathrm{i}}=54$.

Seery, M. K., \& O'Connor, C. (2015). E-learning and blended learning in chemistry education. In J. García-Martínez \& E. Serrano-Torregrosa (Eds.). Chemistry Education: Best Practices, Opportunities and Trends. Weinheim, Germany: Wiley VCH, pp. 651-669. https://doi. org/10.1002/9783527679300.ch26.

Shaine, M. H. (2015). The effect of self-regulated learning strategies and self-efficacy on academic achievement of primary school students. Psychology and Behavioral Sciences, 4(3), 107-115. https://doi. org/10.11648/j.pbs.20150403.14.

Sirhan, G. (2007). Learning difficulties in chemistry: An overview. Journal of Turkish Science Education, 4(4), 2-20. http://www.tused.org/index.php/tused/ article/view/664.

Tayebinik, M., \& Puteh, M. (2012). Blended learning or e-learning? International Magazine on Advances in Computer Science and Telecommunications, 3(1), 103-110. http://ssrn.com/ abstract $=2282881$.

Tekane, R., Pilcher, L. A., \& Potgieter, M. (2019). Blended learning in a second year organic chemistry class: Students' perceptions and preferences of the learning support. Chemistry Education Research and Practice, 21(1), 24-36. https://doi. org/10.1039/c9rp00099b.
Uzuntiryaki, E. (2008). Exploring the sources of turkish pre-service chemistry teachers. Australian Journal of Teacher Education, 33(6), 12-28. https://doi.org/10.14221/ ajte.2008v33n6.2.

Williams, N. A., Bland, W., \& Christie, G. (2008). Improving students' achievement and satisfication by adopting a blended learning approach to inorganic chemistry. Chem. Educ. Res. P Chemistry Education Research and Practice, 9(1), 43-50. https://doi.org/10.1039/b801290n.

Wiyarsi, A., Pratomo, H. \& Priyambodo, E. (2020). Vocational high school students' chemical literacy on context-based learning: a case of petroleum topic. Journal of Turkish Science Education, 17(1), 147- 161. https://doi.org/10.36681/ tused.2020.18.

Woldeamanuel, M., Atagana, H., \& Engida, T. (2014). What makes chemistry difficult? African Journal of Chemical Education, 4(2), 31-43. https://www.ajol.info/index. php/ajce/article/view/104070.

Yasar, O., \& Adiguzel, T. (2010). A working successor of learning management system: SLOODLE. Procedia Social and Behavioral Sciences, 2, 5682-5685.https:// doi.org/10.1016/j.sbspro.2010.03.928.

Yüksel, I., \& Üniversitesi, E. O. (2014). Investigating the impact of classroom management course on self-efficacy levels: An experimental study on pre-service teachers. Education and Science, 39(171), 259-269. http://eb.ted.org.tr/index.php/ EB/article/download/2289/644.

Yurt, E. (2014). The predictive power of self-efficacy sources for mathematics. Education and Science, 39(176), 159-169. https://doi.org/10.15390/EB.2014.3443.

Zimmerman, B. J. (2000). Self efficacy: An essential motive to learn. Contemporary Educational Psychology, 25(1), 82-91. https://doi.org/10.1006/ceps.1999.1016. 